\title{
ONLINE ÖNKÉNTESSÉG - A SEGÍTÉS 21. SZÁZADI FORMÁJA
}

MARKOS VALÉRIA ${ }^{1}$

Filipa Silva - Teresa Proença - Marisa R. Ferreira (2018): Volunteers'perspective on online volunteering - a qualitative approach, International Review on Public and Nonprofit Marketing, 15(2) pp. 531-552.

Kathrin Ackermann - Anita Manatschal (2018): Online volunteering as a means to overcome unequal participation? The profiles of online and offline volunteers compared. Online volunteering as a means to overcome unequal participation? The profiles of online and offline volunteers compared. New Media and Society, 20(12) pp. 4453-4472.

Jennifer Ihm (2017): Classifying and Relating Different Types of Online and Offline Volunteering. Voluntas, 28(1) pp. 400-419.

DOl: https://doi.org/10.53585/OnkSzem.2021.2.125-131

Az internet és az információs technológia térnyerésével az online világ az élet egyre nagyobb területét áthatja, így a munkaerőpiac átalakulásában is jelentős változásokat tapasztalhatunk. Akár fizetett, akár fizetetlen munkáról beszélünk, az offline munkavégzést egyre több területen felváltja az online munkavégzés. Az önkéntes munkát vizsgáló kutatások többsége a személyes részvételen alapuló tevékenységeket vizsgálja, többek között az offline önkéntesek motivációit vagy a társadalmi hátterük jellemzőit. Az elmúlt években az egyre népszerűbbé váló online önkéntesség vizsgálata központi kutatási területté vált.

\footnotetext{
${ }^{1}$ Markos Valéria (PhD) szociológus, kutató-elemző, Kopp Mária Intézet a Népesedésért és a Családokért
} 
A következőkben három nemzetközi tanulmány ismertetésével mutatjuk be az online önkéntesség jellemzőit, az önkéntesek motivációit és tapasztalatait, valamint az önkéntesek társadalmi hátterét. A tanulmányok kiválasztása kapcsán fontos szempont volt, hogy európai és Európán túli szerzők tanulmányait egyaránt ismertessük, így egy nemzetközileg átfogó képet kaphatunk az online önkéntességről a nemzetközi kutatási eredmények tükrében. A módszertan tekintetében kvalitatív és kvantitatív tanulmányokat egyaránt megcéloztunk. Mivel az online önkéntességgel kapcsolatban az utóbbi 5-6 évben jelentek meg rendszeres tanulmányok, így a 2017 után született munkákat részesítettük előnybe a recenzió során.

\section{AZ ONLINE ÖNKÉNTESSÉG MEGHATÁROZÁSA}

Az alábbiakban a kiválasztott, három nemzetközi tanulmányban foglaltak alapján mutatjuk be az online önkéntesség legfőbb jellegzetességeit. Az önkéntesség tevékenységvégzés esetén különbséget tehetünk formális és informális, azaz valamilyen szervezethez kötődő, vagy szervezeten kívüli, a mindennapi életben végzett önkéntes tevékenységek között.

A csoportosítás egy másik szempontját az időráfordítás mértéke alkotja, azaz rendszeres vagy alkalmi önkéntes tevékenységvégzésről van-e szó. Rendszeresen önkénteskedőknek tekinthetjük azokat, akik havonta legalább egy alkalommal, legalább egy éven keresztül végeznek önkéntes tevékenységet, míg az alkalmi önkéntesség esetén ettől ritkább önkénteskedésről beszélünk.

$A z$ önkéntesség csoportosítható a szerint is, hogy online vagy offline történik a tevékenységvégzés. Online önkéntességről akkor beszélünk, ha a végzett tevékenység részben vagy teljes egészében az online térben zajlik.

Ezek a csoportosítások természetesen egyszerre is jellemezhetik az önkéntességet, hiszen lehet szó formális, online önkéntességről vagy akár informális, offline önkéntességről is. A formális online önkéntesség esetén az önkéntes számára lehetőség nyílik arra, hogy akár otthonról végezzen segítő tevékenységet és támogasson valamilyen szervezetet. Az online önkéntesség azonban lehet informális önkéntesség is, mely során az önkéntes közvetlen módon vesz részt egy tevékenységekben az online térben.

A tanulmányok az online végezhető leggyakoribb önkéntes tevékenységek kapcsán az alábbiakat említették: felmérések készítése és adatok elemzése, közösségi oldalak és online tartalmak kezelése (hírlevelek, adatbázisok, weboldalak), Youtube oktatóanyagok és videók készítése, fordítási feladatok elvégzése, tanulmányírás, adatbázisok kezelése, programozás és 
szoftverfejlesztés, könyvelés, marketing és menedzsment feladatok ellátása. Bármilyen feladatot is lát el az önkéntes, időráfordítást és gyakran szakmai tudást igényel részéről, de az is fontos, hogy a végzett tevékenységgel másokon segíthessen, a közösség profitálni tudjon belőle.

\section{AZ ONLINE ÖNKÉNTESSÉG ELŐNYEI}

A tanulmányok szerzői az online önkéntesség egyik legnagyobb előnyének említették, hogy az online tér lehetőséget nyújt azoknak a személyeknek a bevonására is, akik fizikai vagy egyéb korlátok miatt nem tudnak csatlakozni egy-egy szervezet munkájához. Ilyen csoportok lehetnek a mozgásukban korlátozottak, az idős korosztály tagjai, az otthoni vagy munkahelyi kötelezettségük miatt kevésbé mobilisak, vagy azok, akik más településen vagy országban élnek, mint ahol az önkéntes tevékenység végezhető lenne. Az online önkéntesség rugalmasságot biztosít nem csak földrajzi értelemben, hanem időben is jobban összekapcsolható az egyén szabadidejével. Míg az offline önkéntesség többségében egy meghatározott időpontban végezhető, addig az online önkéntesség megvalósítása rugalmasabban alakítható.

Az online önkéntesség rugalmassága különösen vonzó lehet a fiatalok számára, akik oktatási intézmények tanulói, vagy szakmai karrierjük elején tartanak, és legfőképp a tapasztalatszerzés céljából önkénteskednek. Az ifjúsági életszakaszban, amelyet általában a fejlődés, az individualizációra való törekvés, a mobilitásra való nagyobb fokú hajlandóság jellemez, az online tér adta időbeli és helybeli rugalmasság kulcsfontosságú tényezővé válhat az önkéntes munkába való bevonásuk tekintetében.

A rugalmasságon és a hozzáférhetőségen túl az online önkéntes tevékenység a legtöbb esetben anonimitással is jár, melyet számos önkéntes az online önkéntesség pozitívumának tekint. Míg a személyes önkéntesség esetén nagyobb szükség van a szociális készségek alkalmazására, mint például a másokkal való együttmúködés, konfliktuskezelési készség, csapatmunka készség, addig az online önkéntesség esetén az egyéni munkavégzés kerül előtérbe. Megjegyzendő, hogy ezáltal az elkötelezettség szintje alacsonyabbá is válhat (pl. kevésbé válhat fontossá a határidők pontos betartása, ha egyedül dolgozik az egyén), mint a face to face önkéntesség esetén. 
Nem csak az egyének, de a szervezetek is profitálhatnak az online önkéntesekből, hiszen növelik a szervezet sokszínűségét, nyitottságát, új nézőpontokat, tudást, készségeket és képességeket visznek a szervezet életébe. Ez a plusz humán erőforrás a szervezet számára költséghatékonyságot is jelenthet, kevesebb fizetett munkaerőt. Olykor azonban további költséget is jelenthet az online önkéntesek fogadása, hiszen a segítő tevékenység különböző szoftverek használatát igényelheti, így a szervezetnek biztosítani kell számukra a folyamatos technikai feltételeket is.

\section{AZ ONLINE ÖNKÉNTESSÉG MOTIVÁCIÓI}

Filipa Silva, Teresa Proença és Marisa R. Ferreira a "Volunteers'perspective on online volunteering - a qualitative approach" című tanulmányukban az online önkéntesség motivációit az alábbiakkal határozták meg: altruizmus, reciprocitás, e-empowerment és/vagy önmegvalósítás, társadalmi motivációk, tanulás és szabadság/rugalmasság.

A kvalitatív vizsgálat eredményei alapján a motivációk tekintetében az online önkéntesség esetén az altruista motivációk tűntek a legjellemzőbbnek, azaz, hogy az önkéntesek másokon segíthessenek, de gyakori motiváció volt a szakmai tapasztalatszerzés, készség- és képességfejlesztés is. Az e-empowerment vagy az önmegvalósítás szintén fontos motiváció, mivel hozzájárul ahhoz, hogy az egyén a személyes identitását kialakíthassa az önkéntesség által. Az online tér adta lehetőségek által az önkéntesek a személyiségük azon vonásait és azokat a tulajdonságaikat közvetíthetik a külvilág felé, melyeket a legfontosabbnak és legértékesebbnek tartanak. Így egy olyan új képet alkothatnak magukról, amely hozzájárulhat az önbecsülésük növeléséhez. Az online önkéntesség motivációi kapcsán a szociális tényezők kevésbé meghatározóak, ugyanakkor mégis jelen vannak. A válaszadók gyakran hiányolták a személyes találkozásokat, ami megnehezítette számukra az interperszonális kapcsolatok kialakítását. A rugalmasság és a szabadság egy új motivációs elem az online önkéntesség esetén, hiszen térben és időben is nagyobb szabadságot biztosít az önkéntesnek a virtuális tér. A sikeres online önkéntes programok során három fontos dologra hívják fel a figyelmet a szerzők: világos tervezés (a célok és az elvárások egyértelműek legyenek), rendszeres kommunikáció és felügyelet, valamint az eredményekből való tanulságok levonása. Mivel a szervezettel való kapcsolat minimális, vagyis általában a tevékenységek elvégzése nem igényel közvetlen kapcsolatot a szervezettel, így az e-vezető személye kiemelten fontos a munka megszervezése, irányítása és ellenőrzése miatt. 


\section{AZ ONLINE ÖNKÉNTESEK TÁRSADALMI JELLEMZŐI}

Kathrin Ackermann és Anita Manatschal „Online volunteering as a means to overcome unequal participation? The profiles of online and offline volunteers compared"címú tanulmányukban arra hívták fel a figyelmet, hogy az online önkéntesség demokratizálhatja az önkéntességhez való hozzáférést azáltal, hogy olyan személyek számára is vonzóvá teheti a tevékenységet, akik korábban nem önkénteskedtek.

A szerzők különböző társadalmi háttértényezők mentén, úgymint a nem, az életkor, az iskolázottság és a társas kapcsolatok, a bizalom szintje és a vallásosság, keresik a különbségeket az online és az offline önkéntesek csoportjai között.

A szerzők alapvető feltevése volt, hogy az offline önkéntes tevékenység megkövetel bizonyos szociodemográfiai tényezőket, erőforrásokat, társadalmi hálózatokat, valamint pszichológiai elkötelezettséget is. Úgy vélték, hogy ezek a tényezők jelentősen befolyásolják az önkéntességhez való hozzáférést, megerősíthetnek bizonyos társadalmi csoportokat, ugyanakkor bevonzhatnak és mobilissá is tehetnek bizonyos egyéneket. A 35 éven felüliek esetén az offline önkéntesek jellemzően nők, magasabb iskolai végzettséggel és szélesebb kapcsolati hálózattal rendelkeznek, vallásosak és a bizalmi szintjük is magasabb. A 35 évnél fiatalabbak esetén kizárólag a magasabb iskolai végzettség és a gyakoribb templomba járás mutatott pozitív összefüggést az offline önkéntességgel.

Ackermann és Manatschal szerint az online önkéntesség rugalmasságából és anonimitásából kifolyólag alacsonyabb szintű elköteleződéssel jár. Az önkéntességbe való bevonódáshoz nincs szükség széleskörű erőforrásokra, közösségi hálózatokra vagy pszichológiai elkötelezettségre. Eközben a technikai készségek és a digitális technológiához való bizonyos vonzalom még fontosabbá válik, ami megmagyarázza, hogy a fiatalok, mint „digitális bennszülöttek”, szívesebben vállalnak online önkéntes munkát. A 35 évnél fiatalabb korosztály körében a férfiak és a szélesebb kapcsolati hálóval rendelkezők végeznek nagyobb eséllyel online önkéntes tevékenységet, a 35 évnél idősebbek esetén azonban a társas kapcsolatoknak már nem mutatkozott szignifikáns ereje.

Az önkéntesek harmadik kategóriája - az online és az offline önkéntesek mellett - azok, akik ötvözik az offline és az online önkéntességet. Jellemzően magasabb végzettséggel rendelkeztek, gyakoribb templomba járók, és magasabb bizalmi szint jellemezte őket, továbbá 
a férfiak nagyobb eséllyel végeztek hibrid önkéntességet - bár a fiatalok esetén a nemi hatás nem érvényesült, ugyanakkor a szélesebb kapcsolati háló nagyobb szerepet játszott.

\section{AZ ONLINE ÉS AZ OFFLINE ÖNKÉNTESSÉG TÍPUSAI}

Jennifer Ihm „Classifying and Relating Different Types of Online and Offline Volunteering" címü tanulmányában az offline és az online térben önkénteskedők aktivitását és elkötelezettségét vizsgálta, mely alapján az offline önkéntesek négy, míg az online önkéntesek három csoportját különböztette meg. Az alacsony, közepes és magas szinten bevonódó önkéntesek mindkét csoportban kirajzolódtak. Az offline önkéntesek negyedik csoportját az állandó önkéntesek alkották.

Az alacsony szinten elkötelezettek csoportjába azok az önkéntesek tartoztak, akik kevés intézményben, kevés alkalommal és kevés ideig önkénteskedtek. Az önkéntesek többsége jellemzően nem tagja önkéntes szervezetnek. Ebbe a csoportba tartoztak az online önkéntesek 63 százaléka, míg az offline önkéntesek 57 százaléka.

A második csoport a középszinten elkötelezettek csoportja volt, akik valamivel több intézményben, gyakrabban és több ideig önkénteskedtek, mint az előző csoport tagjai. A középső csoportba tartozók alkották az online és az offline válaszadók negyedét.

A magas szintű online önkéntesek olyan aktív résztvevőkből álltak, akik számos szervezetnél önkénteskedtek, gyakran és hosszú ideig. Ők alkották az online válaszadók 11 százalékát, míg az offline válaszadók 12 százalékát.

Az online önkéntesek esetén a közepes és magas szinten elkötelezett önkéntesek csoportjába tartozók jellemzően több mint két szervezetben vettek részt, több mint három éven át. Ők képviselték az aktív online önkéntesek új csoportját, akik kihasználták a kortárs média előnyeit az önkéntes szerepvállalásuk során. Ugyanakkor a közepes és magas szinten elkötelezett önkéntesek közötti különbséget jelezte, hogy a magas szinten elkötelezettek csaknem háromszor olyan gyakran önkénteskedtek, mint a közép szinten elkötelezett csoport tagjai.

Az offline önkéntesek esetén a negyedik csoportot az állandó önkéntesek alkották, akik a többi csoporthoz képest jóval több intézményben önkénteskedtek, a leghosszabb ideig, több mint húsz évig. Ők az offline önkéntesek 5 százalékát tették ki.

Az offline és az online önkénkéntesség kapcsolatát is vizsgálta a szerző, ahol pozitív kapcsolatot fedezett fel. Megállapította, hogy azok, akik magas szinten vettek részt az egyik szférában, szintén magas szinten vonódtak be a másik szférába is. Az online szféra tehát nem 
helyettesítette az offline önkéntességet. Az önkéntesség mindkét térben megjelenhetett akár párhuzamosan is kiegészítve egymást.

\section{ÖSSZEGZÉS}

Recenziónkban az elmúlt évek három kiemelkedő nemzetközi tanulmányát tekintettük át, melyek az online önkéntesség megjelenését és jellemzőit vizsgálták. Megállapítottuk, hogy ez a csoport az önkéntesség jellemzőiben, az önkéntesek motivációiban és társadalmi hátterük mentén is különböztek az offline önkéntesektől.

Az online lehetőségek az önkéntesség terén olyan új lehetőségeket rejtenek, melyek új társadalmi csoportok befogadására képesek, rugalmasságával azokat is bevonzhatja, akik korábban nem végeztek önkéntes munkát. A tanulmányok több olyan előnyét is hangsúlyozzák az online önkéntességnek, melyre az offline tér nem nyújt teret (jobban összeegyeztethető a szabadidővel, nagyobb fokú anonimitás, más készségeket igényel stb.). Az online és az offline önkéntesség között szoros és pozitív kapcsolat áll fent, az egyik szférában végzett tevékenység jól kiegészítheti a másik szférában végzett tevékenységet.

Összességében tehát megállapíthatjuk, hogy az online tér az önkéntesek bevonásában, toborzásában és az önkéntes tevékenységben való részvétel tekintetében, továbbá az önkéntes motivációk mentén új lehetőségeket teremt. 